Jan Józef Janicki

Uniwersytet Papieski Jana Pawta II w Krakowie

\title{
Odnowa śpiewu i muzyki kościelnej - aktualność przestania św. Piusa X w Inter sollicitudines pastoralis officii z 22 listopada 1903 roku
}

\section{1. Święty Pius X, papież - „Odnowiciel wszystkiego w Jezusie Chrystusie"}

Wiek XIX był szczególnie trudnym czasem dla życia Kościoła, który znalazł się pod wpływem bardzo negatywnych dla życia chrześcijańskiego skutków rewolucji francuskiej oraz stanął w obliczu nowego, silnego zagrożenia dla życia religijnego, jakim stały się rozpowszechniane ateizm i materializm ${ }^{1}$. Pomimo tego ten okres dziejów Kościoła stał się wiekiem odnowy, opartej na dokładnym przestrzeganiu tradycji katolickiej według nauczania Magisterium Ecclesiae - Urzędu Nauczycielskiego Kościoła, według ścisłych norm liturgicznych oraz według duchowości rzymsko-łacińskiej². Wiek ten stał się również czasem odszukiwania ukrytych skarbów, które istniały w Kościele od dawna; dokonywało się to poprzez rozwój nauk historycznych zajmujących się początkami Kościoła, w tym badaniami nad liturgią. Wysiłkom katolickich teologów towarzyszyła pobożność eucharystyczna, która znajdowała swój wyraz w kongresach eucharystycznych i która ogarniała coraz szersze kręgi wierzących ${ }^{3}$.

1 Por. M. Banaszak, Historia Kościoła katolickiego, t. 3*, Czasy nowożytne 1758-1914, Warszawa 1991 , s. 362 .

2 Zob. B. Neunheuser, Sto lat ruchu odnowy liturgicznej zapoczatkowanej przez o. Prospera Guéranger. Przesztość i perspektywy, „Ruch Biblijny i Liturgiczny” 29 (1976), s. 198.

3 Por. B. Neunheuser, Sto lat ruchu odnowy liturgicznej zapoczattkowanej przez o. Prospera Guéranger, dz. cyt. Zaznaczmy, że przy pisaniu niniejszego artykułu autor korzystał z dwóch artykułów swojego autorstwa: "Instaurare omnia in Christo” papieża św. Piusa X (19031914) - a odnowa liturgiczna, „Folia Historica Cracoviensia” 10 (2004), s. 167-181 oraz Święty Pius X (1903-1914) - papież Eucharystii, „Kieleckie Studia Teologiczne” 10 (2011), s. 191-213. 
Pośród różnych działań mających na celu odnowę życia chrześcijańskiego podejmowanych przez Kościół w XIX i na początku wieku XX odnowa liturgii zaczęła najbardziej wzbogacać jego życie religijne. W liturgii zaczęto na nowo dostrzegać istotę życia chrześcijańskiego i w niej szukano jego odnowy ${ }^{4}$; „nie tylko nowymi środkami oddziaływania”, ale nadając życiu Kościoła „wyraz tak potrzebnej powagi i dostojeństwa"s. Przykładowa i klasyczna celebracja liturgiczna w klasztorach (głównie benedyktyńskich) oraz „apostolskie” usiłowania „wyjścia” z taką liturgią do wszystkich wiernych stały się rysem charakterystycznym tzw. ruchu liturgicznego ${ }^{6}$.

O ile odnowa liturgiczna po Soborze Watykańskim II mająca za cel „nieustanne pogłębianie chrześcijańskiego życia wiernych”7 dokonuje się niejako „odgórnie” i w całym Kościele, o tyle zwłaszcza druga połowa XIX i pierwsze dekady XX wieku były dziełem „oddolnym” poszczególnych promotorów, tych, którzy byli liturgiae cultores et amatores oraz takich ośrodków, jak Solesmes, Maria Laach, Mont-César (Louvain), Beuron czy Klosterneuburg.

Pierwszą i najbardziej autorytatywną osobą pokazującą liturgię jako źródło życia duchowego dla każdego chrześcijanina, a nie tylko dla niewielkich „wybranych” grup wiernych, stał się papież Pius $\mathrm{X}^{8}$, „pasterz dusz”, który programem swojej posługi apostolskiej uczynił hasło: Instaurare omnia in Christo ${ }^{9}$. Przyjęcie

4 Por. L. Beauduin, Modlitwa Kościota, przekł. i wprow. S. Koperek, Kraków 1987, s. 53.

5 Z. Zieliński, Papiestwo i papieże dwóch ostatnich wieków, cz. 2, Poznań 1986, s. 16.

6 Zob. B. Neunheuser, Sto lat ruchu odnowy..., dz. cyt., s. 198.

7 Sobór Watykański II, konst. Sacrosanctum Concilium [dalej: KL], 1.

8 W pierwszych dniach sierpnia 2013 roku minęła sto dziesiąta rocznica wyboru kard. Giuseppe Melchiorre Sarto na stolicę Piotrową jako Piusa X, a konklawe, podczas którego doszło do jego wyboru, w sposób szczególny należy do wydarzeń historycznych Kościoła. W czasie jego trwania bowiem po raz ostatni w dziejach papiestwa zastosowano weto, które w imieniu cesarza Austro-Węgier Franciszka Józefa I zgłosił biskup krakowski kardynał Jan Puzyna. Cesarz posłużył się ekskluzywą, aby nie dopuścić do wyboru na papieża kardynała Mariano Rampolla. W Archiwum Kapitulnym na Wawelu ks. prof. Jacek Urban odnalazt nieznane dotąd historykom źródło dotyczące tematyki owego weto: jest nim relacja samego biskupa krakowskiego kard. Jana Puzyny, który weto osobiście przedstawił w imieniu cesarza Franciszka Józefa I. Zob. J. Urban, Relacja kard. Jana Puzyny o konklawe 1903 r. i o jego stynnym weto, „Folia Historica Cracoviensia” 8 (2002), s. 273-276.

9 Por. Z. Zieliński, Papiestwo i papieże..., dz. cyt., s. 10 n.; Autor uważa, iż program papieski zawarty w haśle: „Odnowić wszystko w Chrystusie” (Instaurare omnia in Christo) „mylnie odczytywano [...] za zapowiedź reformy, tu chodziło po prostu o urządzanie wszystkiego w Chrystusie, o pozytywne działanie. To było coś znacznie więcej niż reformy. Pius X z góry wykluczył jakiekolwiek kompromisy ze światem, który odchodzi od Chrystusa, zdradzał swoją świadomość nadciągającej ofensywy zła, zeświecczenie. Swoją rolę w obliczu tych zja- 
takiej dewizy oznaczało dla tego papieża odrodzenie społeczeństwa chrześcijańskiego nie tylko poprzez żarliwą obronę praw Chrystusa i Jego Kościoła, lecz również podejmowanie pozytywnego dzieła reform i inicjatyw, „których cel był w zasadzie duszpasterski, a które zmierzały do pogłębienia życia wewnętrznego i lepszego wykorzystania jego zasobów. Pius X zabrał się do tego dzieła z doświadczeniem czterdziestu lat spędzonych z dala od Kurii Rzymskiej na różnych szczeblach aktywnej posługi duszpasterskiej - z całą jasnością i przedsiębiorczością, których dowody dał, kierując diecezjami Mantui i Wenecji”"10.

Święty Pius X, papież - „Odnowiciel wszystkiego w Jezusie Chrystusie” - rozpoczął swój pontyfikat od uroczystego potwierdzenia słuszności rozwijającego się ruchu liturgicznego. Zaznaczył, że aby odnowić prawdziwego ducha chrześcijańskiego, trzeba przyprowadzić całą wspólnotę wierzących do pierwszego i nie do zastąpienia przez inne formy pobożności źródła tego ducha, a mianowicie do czynnego udziału wiernych w liturgii, określonej przez Piusa X jako święte misteria (tajemnice), a także do publicznej i uroczystej modlitwy Kościoła. Papież nauczał:

Jest naszym najgorętszym pragnieniem, aby prawdziwy duch chrześcijański na nowo rozkwitł na wszelki sposób i ogarnął wszystkich wiernych. Jest więc rzeczą konieczną zatroszczyć się przede wszystkim o świętość i godność świątyni, gdzie wierni się gromadzą właśnie, aby szukać owego ducha chrześcijańskiego w jego pierwszym i niezastąpionym źródle, to znaczy

wisk widział w postaci budowniczego królestwa Bożego wbrew ludzkim względom i rachubom. Nie wątpił też ani na chwilę, że zwycięstwo należy do sprawy Bożej. Nie trzeba tylko wahać się, gdy przychodzi demaskować szatana, i nie wolno z nim paktować, zaraz bowiem zatruje on życie społeczne i prywatne. Chrystus jest jedyną zasadą odnowy religijnej, a powrót do Niego oznacza rezygnację z nieokiełznanej wolności, której ludzie domagają się dlatego, by móc czynić zło. Papież więc zapowiada walkę z siłami zła, a po to, by móc ją prowadzić, trzeba przede wszystkim usprawnić szeregi duchowieństwa, wyznaczyć mu odpowiednią rolę. Pius X zalecał więc zastosowanie wszelkich środków ku temu podanych przez Sobór Trydencki” (Z. Zieliński, Papiestwo i papieże..., dz. cyt., s. 11).

${ }^{10}$ R. Aubert, Kościót katolicki od kryzysu 1848 roku do pierwszej wojny światowej, [w:] Historia Kościota, t. 5, 1848 do czasów wspótczesnych, red. L. J. Rogier, R. Aubert, M. D. Knowles, przeł. T. Szafrański, Warszawa 1985, s. 18. Roger Aubert uważa, że papież Pius X nie pozwolił się „opanować” biurokracji i dlatego przeprowadził w ciągu krótkiego czasu (jego pontyfikat trwał tylko jedenaście lat) wiele reform, o które dopominano się w Kościele od stuleci, a które w owym czasie uważano także za rewolucyjne. Były to m.in. dekrety dotyczące komunii świętej dzieci i częstego jej przyjmowania przez dorosłych, muzyki kościelnej i liturgii, a ponadto wskazania kierowane do ogółu świeckich, które sprawiły, że Pius X został uznany za pioniera Akcji Katolickiej. 
w czynnym udziale w Świętych Misteriach oraz w publicznej i uroczystej modlitwie Kościoła ${ }^{11}$.

Papież Pius X, podejmując się realizacji swego programu „odnowienia wszystkiego w Chrystusie" w dziedzinie liturgii, skoncentrował swe działania przede wszystkim na odnowie śpiewu i muzyki liturgicznej (motu proprio Inter sollicitudines pastoralis officii - Tra le sollecitudini - z 22 listopada 1903 roku), zachęcie skierowanej do dorosłych do częstego, codziennego przyjmowania komunii świętej (dekret Sacra Tridentina Synodus z 20 grudnia 1905 roku), na dopuszczeniu dzieci do (pierwszej) komunii świętej (dekret Quam singulari Christus amo$r e-\mathrm{z} 8$ sierpnia 1910 roku) oraz na reformie brewiarza, czyli officium divinum („dzisiejszej” Liturgii godzin - codziennej modlitwie Ludu Bożego) (motu proprio Divino afflatu Spiritu - z 11 listopada 1911 roku) ${ }^{12}$.

\section{Motu proprio Tra le sollecitudini (22 listopada 1903 roku)}

Odnowę liturgii rozpoczął papież św. Pius X od reformy śpiewu i muzyki kościelnej, której bardzo głębokich i skutecznych oddziaływań doświadczył już jako biskup Mantui, szczególnie kiedy Kongregacja Obrzędów opublikowała 24 grudnia 1884 roku dekret o nadużyciach w muzyce kościelnej ${ }^{13}$. Mając to na uwadze, biskup Giuseppe Melchiorre Sarto zatroszczył się o poprawne wykształcenie muzyczne alumnów seminarium diecezjalnego oraz duchowieństwa swojej diecezji. W dniu 1 maja 1895 roku jako kardynał - patriarcha Wenecji (1893-1903) - ogłosił swój słynny list pasterski De musica sacra, który wywołał wielkie poruszenie wśród ówczesnych muzyków. Tenże list pasterski i doświadczenia weneckie, z których wiele Pasterz ów przenosił do życia Kościoła powszechnego, stały się niejako fundamentem powstania dokumentu o charakterze motu

${ }^{11}$ Cyt. za: L. Beauduin, Modlitwa Kościota, dz. cyt., s. 84; zob. tłumaczenie [w:] G. M. Suñol, Zasady śpiewu gregoriańskiego, tłum. M. Koziura, Poznań 1957, s. 216.

12 Por. M. Righetti, Storia liturgica, t. 1, Introduzione generale, Milano 1964³ , s. 52; O. Rousseau, Storia del movimento liturgico, Roma 1961, s. 239; R. Aubert, Das Reformwerk Pius'X. Eucharistische Dekrete und liturgische Erneuerung, [w:] Die Kirche in der Gegenwart, VI/2. Die Kirche zwischen Anpassung und Widerstand, hrsg. H. Jedin, Freiburg 1985, s. 416-426; R. Aubert, Kościót katolicki od kryzysu..., dz. cyt., s. 7-21; A. Haquin, Les décrets eucharistiques de Pie X. Entre mouvement eucharistique et mouvement liturgique, „La Maison Dieu” 203 (1995), s. 61-82.

${ }^{13}$ Zob. G. Mizgalski, Pius X, [w:] G. Mizgalski, Podręczna encyklopedia muzyki kościelnej, Poznań 1959, s. 378. 
proprio $^{14}$, noszącego nazwę Tra le sollecitudini (Inter sollicitudines pastoralis officii). Został on wydany dnia 22 listopada 1903 roku w liturgiczne wspomnienie św. Cecylii, dziewicy i męczennicy, patronki muzyki kościelnej ${ }^{15}$. Święta Kongregacja Obrzędów dekretem z dnia 8 stycznia 1904 roku ogłosiła ten dokument papieski „prawomocną ustawą o muzyce kościelnej”"

Ojciec święty Pius X w motu proprio z dnia 22 listopada 1903 roku wydanym w formie instrukcji o muzyce kościelnej (Instructio de musica sacra), przywrócił szczęśliwie czcigodny śpiew gregoriański, według ksiąg starożytnych, do pierwotnego użycia w kościołach i zarazem w jedną całość zebrał główne przepisy, mające na celu pomnożenie lub przywrócenie w świątyniach świętości i godności śpiewów, rozkazując z mocy pełności Apostolskiej swej Władzy, aby ten zbiór jako kodeks prawomocny muzyki kościelnej miał obowiązującą siłę prawa. W tym celu tenże sam Ojciec święty przez tę Świętych Obrzędów Kongregację poleca i nakazuje, aby wszystkie kościoty powyższą Instrukcję przyjęły i święcie się do niej zastosowały, bez względu na przywileje i wyjątki jakiekolwiek, nawet najdalej posunięte, jakimi są przywileje i wyjątki przez Stolicę Świętą Bazylikom Większym Miasta Rzymu, szczególnie zaś przesławnej Bazylice Lateraneńskiej udzielone. Zarówno cofając, czy to przywileje, czy zalecenia, które Stolica Apostolska lub ta Święta Kongregacja stosownie do czasów i okoliczności na różne nowsze wydania śpiewu liturgicznego dawała, tenże Ojciec święty łaskawie zezwolić raczył, aby te wyżej wzmiankowane nowsze wydania śpiewu liturgicznego, w tych kościołach, w których już zaprowadzone zostały, mogły być zachowane i używane dopóty, dopóki, oby najprędzej, czcigodny śpiew gregoriański, według autentycznych ksiag, na ich miejsce nie będzie zaprowadzony. Postanowienie to obowiązuje mimo wszelkich innych mu przeciwnych przepisów i zwyczajów. Ojciec Święty Pius X nakazał tejże Świętych Obrzędów Kongregacji o tym wszystkim niniejszy Dekret wydać dnia 8 stycznia 1904 roku $^{17}$.

${ }^{14}$ Łacińskie określenie: „motu proprio”, czyli: z wtasnej inicjatywy oznacza „wydane przez papieża zarządzenie, niekiedy nawet bez osobliwych formalności” (A. Jougan, Stownik kościelny tacińsko-polski, Poznań 1958,s. 433).

${ }^{15}$ Pius X, Motu proprio Tra le sollecitudini (22 XI 1903), Wstęp; polskie tłumaczenie [w:] G. M. Suñol, Zasady śpiewu, dz. cyt., s. 213-226. Por. B. Neunheuser, Sto lat ruchu odnowy liturgicznej..., dz. cyt., s. 198; Z. Zieliński, Papiestwo i papieże..., dz. cyt., s. 16; M. Kunzler, Liturgia Kościota, Poznań 1999, s. 208.

${ }^{16}$ G. M. Suñol, Zasady śpiewu, dz. cyt., s. 225; por. G. Mizgalski, Podręczna encyklopedia muzyki kościelnej, dz. cyt., s. 378.

${ }_{17}$ G. M. Suñol, Zasady śpiewu, dz. cyt., s. 225 n. 
We Wstępie do motu proprio o muzyce świętej, dokumentu określanego jako Ustawa prawomocna o muzyce kościelnej ${ }^{18}$, papież Pius X napisał, że

jedną z ważnych trosk urzędu Pasterskiego, nie tylko na tej najwyższej Stolicy Biskupiej, [...] ale i w każdym pojedynczym kościele, stanowi zadanie utrzymania i podniesienia uroku Domu Bożego, w którym odbywają się wzniosłe tajemnice religijne i w którym lud wierny się zgromadza, aby dostąpić łask sakramentalnych, uczestniczyć w świętej Ofierze Ołtarza, uczcić Przenajświętszy Sakrament Ciała Pańskiego i połączyć się we wspólnej modlitwie, zanoszonej przez Kościół wśród wzniosłych czynności liturgicznych. Nic zatem nie powinno wydarzyć się w świątyni, co by przeszkadzało, lub choćby tylko zmniejszało pobożność i skupienie ducha wiernych; nic, co by stanowiło słuszną przyczynę niesmaku lub zgorszenia, a nade wszystko nic, co by wprost obrażało powagę i świętość kościelnych czynności i tym samym stawało się niegodnym Domu Modlitwy i Majestatu Bożego ${ }^{19}$.

Ojciec święty Pius X, kierując do całego Kościoła powszechnego zaraz na początku swego pontyfikatu stosunkowo obszerną i poniekąd surową instrukcję o śpiewie i muzyce kościelnej, uznał, że wymaga tego zaistniała sytuacja nadużyć w tej dziedzinie życia Kościoła. Papież, nie określając szczegółowo owych „nadużyć”, które mogą się wydarzyć, stwierdza, iż chodzi o jedno „z najzwyklejszych i najtrudniejszych do wykorzenienia nadużyć, nad którym trzeba nieraz ubolewać w takich nawet miejscowościach, w których każda inna rzecz godną jest najwyższej pochwały”, jak piękno i wspaniałość świątyni, „wzorowy porządek ceremonii”, powaga duchowieństwa i „pobożność, z jaką kapłani spełniają święte czynności”20.

W swoim motu proprio z 22 listopada 1903 roku Pius X mówi o dwóch złożonych przyczynach tychże nadużyć, z których jedne płyną z „właściwości tej sztuki, samej w sobie chwiejnej i zmiennej”; ze zmiany u wielu ludzi (z biegiem lat) „smaku i przyzwyczajeń”; na skutek „nieszczęsnego wpływu sztuki świeckiej i teatralnej na sztukę kościelną”; ze względu na „przyjemność, którą muzyka bezpośrednio sprawia i którą nie zawsze łatwo utrzymać w odpowiednich granicach”

${ }^{18}$ Pius X, Motu proprio, Tra le sollecitudini..., tłum. [w:] G. M. Suñol, Zasady śpiewu, dz. cyt., s. 213.

${ }_{19}$ Pius X, Motu proprio, Tra le sollecitudini..., tłum. [w:] G. M. Suñol, Zasady śpiewu, dz. cyt., s. $214 \mathrm{n}$.

${ }^{20}$ Pius X, Motu proprio, Tra le sollecitudini..., tłum. [w:] G. M. Suñol, Zasady śpiewu, dz. cyt., s. 215. 
i wreszcie „skutkiem wielu uprzedzeń, które w tej sprawie niepostrzeżenie powstają" ${ }^{21}$. Do drugiej grupy przyczyn, które spowodowały to jedno „z najzwyklejszych i najtrudniejszych do wykorzenienia nadużyć”, należy w opinii papieskiej - nawet „u osób poważnych i pobożnych” - uporczywe i ciągłe dążenie „do zbaczania od prostej normy ustanowionej przez cel, dla którego sztuka (muzyka) jest oddana na usługi kultu"22. Pius X przypomina, że ten cel muzyki i śpiewu został jasno wyrażony „w kanonach kościelnych” (tzn. w zasadach, normach, prawa Kościoła), „w rozporządzeniach Soborów powszechnych i prowincjonalnych”, a także w przepisach wielokrotnie wydawanych przez święte rzymskie kongregacje i przez papieży. Ojciec święty zauważa, iż wiele dobrego dokonało się w tym względzie w Rzymie i we Włoszech, ale o wiele więcej w innych krajach, gdzie „znakomici mężowie” "gorliwi o chwałę Bożą", połączyli się, za pozwoleniem Stolicy Świętej i pod kierunkiem swoich biskupów, „w kwitnące stowarzyszenia i prawie w każdym swym kościele i kaplicy przywrócili zaszczytne miejsce należne muzyce kościelnej”23. Należy jednak „zganić i potępić wszystko to, co w świętych czynnościach i obrzędach kościelnych niezgodne jest z istniejącymi przepisami" ${ }^{24}$. „Najgorętszym pragnieniem” papieża stało się, aby na powrót rozkwitł i utrzymywał się wśród wiernych „prawdziwy duch chrześcijański”, którego wierni mogą zaczerpnąć „z najpierwszego i niezbędnego źródła, jakie stanowi czynny współudział w najświętszych tajemnicach oraz modłach publicznych i uroczystych Kościoła” ${ }^{25}$. „Celebracja liturgiczna i czynne w niej uczestnictwo wiernych jest więc głównym źródłem ducha chrześcijańskiego"26.

Papież Pius X uznał, iż byłoby rzeczą daremną spodziewać się „,obfitego błogosławieństwa niebios”, jeżeli sposób, w jaki wierni zanoszą do Boga swe błagania, „zamiast wznosić się "W wonności wdzięczności», wciskać Mu będzie do ręki powrozy, którymi Boski Zbawiciel wyganiał ongiś ze świątyni niegodnych, którzy ją bezcześcili”27.

${ }^{21}$ Pius X, Motu proprio, Tra le sollecitudini..., tłum. [w:] G. M. Suñol, Zasady śpiewu, dz. cyt., s. 215.

${ }^{22}$ Pius X, Motu proprio, Tra le sollecitudini..., tłum. [w:] G. M. Suñol, Zasady śpiewu, dz. cyt., s. 215.

${ }^{23}$ Pius X, Motu proprio, Tra le sollecitudini..., tłum. [w:] G. M. Suñol, Zasady śpiewu, dz. cyt., s. 215.

${ }^{24}$ Pius X, Motu proprio, Tra le sollecitudini..., tłum. [w:] G. M. Suñol, Zasady śpiewu, dz. cyt., s. 215.

${ }^{25}$ Pius X, Motu proprio, Tra le sollecitudini..., tłum. [w:] G. M. Suñol, Zasady śpiewu, dz. cyt., s. 215.

${ }^{26}$ B. Neunheuser, Sto lat ruchu odnowy liturgicznej, dz. cyt., s. 198.

${ }^{27}$ B. Neunheuser, Sto lat ruchu odnowy liturgicznej, dz. cyt., s. 198. 
Mając na uwadze wszystkie powyższe racje, a także intencję, by „znikła wszelka niepewność w tłumaczeniu niektórych już wydanych przepisów”, papież postanowił „wskazać w krótkości te zasady, które winny kierować muzyką kościelną w świętych obrzędach, oraz zebrać w jedną ogólną całość główne przepisy Kościoła, wydane przeciw najpospolitszym nadużyciom w tej sprawie"28.

\subsection{Muzyka integralną częścią liturgii}

Muzyka kościelna w nauczaniu Piusa X w jego motu proprio z 22 listopada 1903 roku to integralna część uroczystej liturgii, z którą dzieli cel ogólny, „jakim jest chwała Boża, uświęcenie i zbudowanie wiernych" ${ }^{29}$. Muzyka kościelna przyczynia się także do powiększenia powagi i wspaniałości ceremonii kościelnych, a „przyodziewając” odpowiednią melodią tekst liturgiczny, dodaje mu większej siły, przyczyniając się do jego lepszego zrozumienia przez wiernych. Za pośrednictwem zatem muzyki wierni jeszcze mocniej są pobudzani do pobożności i skuteczniej usposobieni do bardziej owocnego korzystania z „owoców łaski, powstających przy sprawowaniu Przenajświętszych Tajemnic ${ }^{30}$.

Ponieważ muzyka kościelna spełnia tak ważną rolę w liturgii, powinna ona mieć cechy właściwe liturgii, a mianowicie: świętość, piękno i doskonałość formy oraz powszechnośćc ${ }^{31}$. Święty Pius X był znawcą i miłośnikiem poważnej muzyki kościelnej i ubolewał już jako młody kapłan i proboszcz nad upadkiem śpiewów pieśni religijnych w kościołach włoskich. Dlatego jako profesor śpiewu łacińsko-gregoriańskiego w seminarium duchownym w Treviso uczył i szerzył znajomość chorału oraz zachęcał (zwłaszcza młodych kandydatów do kapłaństwa) do starannego wykonywania melodii gregoriańskich, a także przestrzegał przed rozmaitymi „nieprawidłowościami” w muzyce i śpiewie kościelnym. Jako pasterz biskup kościoła w Mantui (1884 rok), a później kardynał i patriarcha Wenecji (1893 rok) z wielką gorliwością pasterską troszczył się o tę zaniedbaną wtedy dziedzinę sztuki, która pozostaje tak ściśle związana z życiem religijnym wiernych. Wymownym świadectwem takiej troski jako patriarchy weneckiego był wystosowany do duchowieństwa i wiernych w 1895 roku list pasterski, w którym podkreślał m.in.,

${ }^{28}$ B. Neunheuser, Sto lat ruchu odnowy liturgicznej, dz. cyt., s. 198.

29 Sobór Watykański II 60 lat później - 4 grudnia 1963 roku - powtórzył w konstytucji o liturgii świętej nauczanie św. Piusa X, iż celem muzyki kościelnej jest chwała Boża i uświęcenie wiernych (zob. KL 112).

${ }^{30}$ Pius X, Instrukcja o muzyce kościelnej, nr 1, cyt. za: G. M. Suñol, Zasady śpiewu, dz. cyt., s. $216 \mathrm{n}$.

${ }^{31}$ Pius X, Instrukcja o muzyce kościelnej, nr 2, cyt. za: G. M. Suñol, Zasady śpiewu, dz. cyt. 
iż śpiew i muzyka kościelna, nieodłącznie powiązane z liturgią, muszą wyróżniać się świętością, doskonałością artystyczną i powszechnością.

Muzyka kościelna powinna być świętą, czyli „wykluczać wszelką świeckośc” w sobie samej i w sposobie jej wykonywania przez uczestników liturgii.

Muzyka święta (musica sacra) winna być prawdziwą i doskonałą artystycznie sztuką, aby mogła skutecznie wywierać wpływ na „dusze tych, którzy jej słuchają”, i to taki wpływ, „jaki Kościół zamierza wywrzeć, przyjmując do swej liturgii sztukę tonów”.

Muzyka używana w liturgii powinna mieć charakter powszechny, tzn. powinna pozwalać każdej narodowości na stosowanie w utworach kościelnych tych form, które stanowią wyłączną cechę ich muzyki. Należy jednak podporządkować te formy „ogólnym cechom muzyki kościelnej, aby nikt z innej narodowości, słuchając jej, nie doznał niedobrego wrażenia” 32 .

\section{2. Śpiew gregoriański wzorem muzyki kościelnej}

Cechę świętości, piękna i doskonałości formy oraz powszechności posia$\mathrm{da}$ - zdaniem Piusa X - „w najwyższym stopniu” śpiew gregoriański, który dlatego jest „śpiewem właściwym Kościoła Rzymskiego”. Jest jedynym śpiewem, który Kościół odziedziczył „po ojcach dawnych” i „którego z zazdrością strzegł przez długie wieki w swych księgach liturgicznych” i który „najnowsze studia tak szczęśliwie przywróciły do pierwotnej nieskazitelności i czystości”33.

Papież nie tylko przypomina, że śpiew gregoriański był zawsze uważany za „pierwowzór muzyki kościelnej”, ale uważa, iż stało się zasadą twierdzenie: „o tyle jakaś kompozycja przeznaczona dla Kościoła jest świętsza i bardziej liturgiczna, o ile więcej w swym przebiegu, w swym natchnieniu i smaku zbliża się do melodii gregoriańskiej; o tyle zaś mniej jest godna świątyni, o ile więcej staje się niezgodna z tym najwyższym wzorem" ${ }^{34}$. Jest dlatego ważną było sprawą przywrócenie śpiewu gregoriańskiego „w obrzędach kultu”, a zatem wśród wiernych, aby i oni „tak jak to dawniej bywało”, znowu „bardziej czynnie uczestniczyli w nabożeństwach kościelnych"35.

${ }^{32}$ Pius X, Instrukcja o muzyce kościelnej, nr 2, cyt. za: G. M. Suñol, Zasady śpiewu, dz. cyt, s. 218.

33 Pius X, Instrukcja o muzyce kościelnej, nr 2, cyt. za: G. M. Suñol, Zasady śpiewu, dz. cyt, s. 218.

${ }^{34}$ Pius X, Instrukcja o muzyce kościelnej, nr 2, cyt. za: G. M. Suñol, Zasady śpiewu, dz. cyt, s. 218.

${ }^{35}$ Pius X, Instrukcja o muzyce kościelnej, nr 2, cyt. za: G. M. Suñol, Zasady śpiewu, dz. cyt, s. 218. 
W muzyce kościelnej (sakralnej) - w myśl dokumentu Piusa X z 22 listopada 1903 roku - nie może zabraknąć miejsca na tzw. „klasyczną polifonię”, która „w wysokim stopniu zbliża się do śpiewu gregoriańskiego”, będącego wzorem muzyki kościelnej. $\mathrm{Z}$ tego tytułu zasługuje, aby obok śpiewu gregoriańskiego była przyjęta „W nabożeństwach kościelnych bardziej uroczystych, jakimi są nabożeństwa ze współudziałem Kapeli Papieskiej” ${ }^{36}$. Szczególnym przykładem jest w tym względzie szkoła rzymska, która „w wieku XVI doszła do szczytu swej doskonałości w utworach Pierluigi da Palestriny i która w dalszym ciągu nie przestaje wydawać dzieł doskonałych pod względem liturgicznym i muzycznym" ${ }^{37}$. Polifonia powinna być „na powrót wprowadzona do kościelnych uroczystości, szczególnie w znaczniejszych bazylikach, kościołach katedralnych, kaplicach seminariów oraz innych instytutów kościelnych, w których dostateczne siły znajdą się do ich wykonania" ${ }^{38}$.

Święty Pius X w swoim pierwszym apostolskim dokumencie poświęconym muzyce świętej (kościelnej) potwierdził, że Kościół dopuszcza „na usługi kultu” wszystko, co „geniusz w ciągu wieków mógł stworzyć dobrego i pięknego, z zachowaniem jednakże zawsze praw liturgii”, i na tej zasadzie dopuszcza także muzykę współczesną, „skoro i ona dostarcza dzieł tak dobrych, poważnych i uroczystych, że stają się całkiem godnymi obrzędów liturgicznych" ${ }^{39}$. Trzeba jednak zwracać uwagę, aby kompozycje muzyczne w najnowszym stylu, które się dopuszcza w Kościele, nie zawierały w sobie nic świeckiego; nie były wzorowane na utworach świeckich czy przeznaczonych do użytku świeckiego oraz nie zawierały „reminiscencji motywów wykonywanych w teatrach”. Papież Pius X wyraźnie stwierdza, że najmniej odpowiedni do stosowania w obrzędach kultu jest „styl teatralny”, który „z natury rzeczy samej staje w największym przeciwieństwie ze śpiewem gregoriańskim i z klasyczną polifonią, a tym samym występuje przeciw prawu zasadniczemu każdej dobrej muzyki kościelnej”º.

Święty Pius X, mówiąc w swoim motu proprio o ważności śpiewu gregoriańskiego, przypomniał, że językiem „właściwym” Kościoła Rzymskiego jest język łaciński i dlatego zakazał w uroczystych czynnościach liturgicznych śpiewać co-

${ }^{36}$ Pius X, Instrukcja o muzyce kościelnej, nr 2, cyt. za: G. M. Suñol, Zasady śpiewu, dz. cyt, s. 218.

37 Pius X, Instrukcja o muzyce kościelnej, nr 2, cyt. za: G. M. Suñol, Zasady śpiewu, dz. cyt, s. 218.

${ }^{38}$ Pius X, Instrukcja o muzyce kościelnej, nr 2, cyt. za: G. M. Suñol, Zasady śpiewu, dz. cyt, s. 218.

${ }^{39}$ Pius X, Instrukcja o muzyce kościelnej, nr 2, cyt. za: G. M. Suñol, Zasady śpiewu, dz. cyt, s. 218.

${ }^{40}$ Pius X, Instrukcja o muzyce kościelnej, nr 2, cyt. za: G. M. Suñol, Zasady śpiewu, dz. cyt., s. 219. 
kolwiek w języku ludowym. Papieskie nauczanie tak wyraźnie zalecające śpiew gregoriański w liturgii sprawiło, iż papież Pius X przez muzyków i liturgistów jest nazywany „odnowicielem” chorału gregoriańskiego.

\section{Streszczenie}

Odnowa śpiewu i muzyki kościelnej - aktualność przestania św. Piusa $X$ w Inter sollicitudines pastoralis officii z 22 listopada 1903 roku

Pośród różnych działań mających na celu odnowę życia chrześcijańskiego podejmowanych przez Kościół w XIX i na początku wieku XX odnowa liturgii zaczęła najbardziej wzbogacać jego życie religijne. W liturgii zaczęto na nowo dostrzegać istotę życia chrześcijańskiego i w niej szukano jego odnowy; „nie tylko nowymi środkami oddziaływania”, ale nadając życiu Kościoła „wyraz tak potrzebnej powagi i dostojeństwa”.

Pierwszą i najbardziej autorytatywną osobą pokazującą liturgię jako źródło życia duchowego dla każdego chrześcijanina, a nie tylko dla niewielkich „wybranych” grup wiernych, stał się papież Pius X, „pasterz dusz”, który programem swojej posługi apostolskiej uczynił hasło: Instaurare omnia in Christo. Papież Pius X, podejmując się realizacji swego programu „odnowienia wszystkiego w Chrystusie” w dziedzinie liturgii, skoncentrował swe działania przede wszystkim na odnowie śpiewu i muzyki liturgicznej (motu proprio Inter sollicitudines pastoralis officii - Tra le sollicitudini). Dokument ten został opublikowany 22 listopada 1903 w liturgiczne wspomnienie św. Cecylii, dziewicy i męczennicy, patronki muzyki kościelnej. Święta Kongregacja Obrzędów dekretem z dnia 8 stycznia 1904 roku ogłosiła ten papieski dokument „prawomocną ustawą o muzyce kościelnej”.

Ojciec święty Pius X w motu proprio z dnia 22 listopada 1903 roku wydanym w formie instrukcji o muzyce kościelnej (Instructio de musica sacra), przywrócił szczęśliwie czcigodny śpiew gregoriański, według ksiąg starożytnych, do pierwotnego użycia w kościołach i zarazem w jedną całość zebrał główne przepisy, mające na celu pomnożenie lub przywrócenie w świątyniach świętości i godności śpiewów, rozkazując z mocy pełności Apostolskiej swej Władzy, aby ten zbiór jako kodeks prawomocny muzyki kościelnej miał obowiązującą siłę prawa.

Ojciec święty Pius X zaraz na początku swego pontyfikatu skierował do całego Kościoła powszechnego stosunkowo obszerną i poniekąd surową instrukcję o śpiewie i muzyce 
kościelnej. Był bowiem przekonany, że wymaga tego zaistniała sytuacja nadużyć w tej dziedzinie życia Kościoła.

\section{Summary}

Restoration of sacred song and music - the relevance of the St. Pius X's message Inter sollicitudines pastoralis officii from 22 ${ }^{\text {nd }}$ November 1903

Restoration of liturgy has become one of the crucial actions aimed at restoration of Christian life undertaken by The Church in the XIX and at the beginning of the XX century. Liturgy one more time became the core of Christian life and the source of its restoration "not only with the new means of influence" but by giving the life of the Church "an expression of required solemnity and dignity".

The first and the most authoritative person presenting the liturgy as a source of the spiritual life of each Christian, and not only of small groups of the "chosen" believers, became the Pope Pius the Xth, "the Sheppard of souls", whose apostolic mission is expressed by the words: "Instaurare omnia in Christo". Undertaking the realization of his programme "restoration of all in Christ" in the field of liturgy, The Pope Pius the Xth, focussed primarily on restoration of the liturgical song and music: motu proprio Inter sollicitudines pastoralis officii - Tra le sollecitudini.

This document was published on $22^{\text {nd }}$ November 1903 in the liturgical memento of the St. Cecilia, a virgin and martyr, the patron of sacral music. On $8^{\text {th }}$ January 1904 the St. Congregation of Ceremonies issued a decree announcing the Pope's document "a legally valid act of sacral music".

The Holy Father Pius X in motu proprio from 22 $2^{\text {nd }}$ November 1903 published in the form of Instruction of the Sacral Music (Instructio de musica sacra), happily restored the honourable Gregorian chants, described in the manuscripts, to the prime use in Churches, and at the same time collected main rules, aiming at enlarging or restoring the sacral dignity of Gregorian Chants. He also, with the Apostolic Power, ordered to make this collection a legal code of sacred music.

The Holy Father Pius X, just at the beginning of his pontificate, directed this relatively voluminous and strict instruction of the sacral chants and music to the whole Church. He was convinced that this was necessary in the situation of a misuse in the field of life of the Church. 
Keywords St. Pius X, song in liturgy, sacral music, Gregorian chants, secular song and music in liturgy, improper sacral music

Słowa kluczowe Św. Pius X, śpiew w liturgii, muzyka kościelna, śpiew gregoriański, śpiew i muzyka świecka w liturgii, niewłaściwa muzyka kościelna

\section{Bibliografia}

Aubert R., Das Reformwerk Pius'X. Eucharistische Dekrete und liturgische Erneuerung, [w:] H. Jedin, Die Kirche in der Gegenwart, VI/2. Die Kirche zwischen Anpassung und Widerstand, Freiburg 1985, s. 416-426.

Aubert R., Kościót katolicki od kryzysu 1848 roku do pierwszej wojny światowej, [w:] Historia Kościota, t. 5, 1848 do czasów wspótczesnych, red. L. J. Rogier, R. Aubert, M. D. Knowles, przeł. T. Szafrański, Warszawa 1985.

Banaszak M., Historia Kościoła Katolickiego, t. 3. Czasy nowożytne 1758-1914, Warszawa 1991.

Beauduin L., Modlitwa Kościota, przekł. i wprow. S. Koperek, Kraków 1987.

Haquin A., Les décrets eucharistiques de Pie X. Entre mouvement eucharistique et mouvement liturgique, "La Maison Dieu” 203 (1995), s. 61-82.

Janicki J. J., „Instaurare omnia in Christo” papieża św. Piusa X (1903-1914) - a odnowa liturgiczna, „Folia Historica Cracoviensia” 10 (2004), s. 167-181.

Janicki J. J., Święty Pius X (1903-1914) - papież Eucharystii, „Kieleckie Studia Teologiczne" 10 (2011), s. 191-213.

Jougan A., Stownik kościelny tacińsko-polski, Poznań 1958.

Kunzler M., Liturgia Kościota, przekł. i oprac. L. Balter, Poznań 1999.

Mizgalski G., Pius X, [w:] Mizgalski G., Podręczna encyklopedia muzyki kościelnej, Poznań 1959, s. 378-379.

Neunheuser B., Sto lat ruchu odnowy liturgicznej zapoczątkowanej przez o. Prospera Guéranger. Przesztość i perspektywy, „Ruch Biblijny i Liturgiczny” 29 (1976), s. 195-207.

Righetti M., Storia l.iturgica, t. 1, Introduzione generale, Milano $1964^{3}$.

Rousseau O., Storia del movimento liturgico, Roma 1961.

Suñol G. M., Zasady śpiewu gregoriańskiego, tłum. M. Koziura, Poznań 1957.

Urban J., Relacja kard. Jana Puzyny o konklawe 1903 r. i o jego stynnym weto, „Folia Historica Cracoviensia” 8 (2002), s. 273-276.

Zieliński Z., Papiestwo i papieże dwóch ostatnich wieków, cz. 2, Poznań 1986. 